\title{
China, Responsibility to Protect, and the Case of Syria
}

From Sovereignty Protection to Pragmatism

\author{
Catherine Gegout \\ School of Politics and International Relations, University of Nottingham, \\ Nottingham, United Kingdom; Jean Monnet Fellow, European University \\ Institute, Firenze, Italy \\ Catherine.Gegout@nottingham.ac.uk \\ Shogo Suzuki \\ Department of Politics, University of Manchester, Manchester, \\ United Kingdom \\ Shogo.Suzuki@manchester.ac.uk
}

\begin{abstract}
Will the rise of China, an authoritarian, party-state with a poor record of protecting its citizens' human rights, undermine humanitarian intervention? This question has been particularly pertinent since China's "assertive turn" in foreign policy. Drawing on the case of Chinese reactions to the humanitarian crisis in Syria, this article argues that China's attitude toward humanitarian intervention remains ambiguous and contradictory. While China has at times prevented the UN Security Council from threatening sanctions on Syria, it has not necessarily denied that a humanitarian crisis exists. The article shows that the People's Republic of China is beginning to act more as a norm maker than norm taker, and is offering its own vision of humanitarian intervention, coined as "responsible protection."
\end{abstract}

\section{Keywords}

humanitarian intervention - sovereignty - responsible protection - norm making China - Syria 
Humanitarian intervention aims specifically at preventing mass killings, genocide, population expulsion, or the use of child soldiers. ${ }^{1}$ The principles of humanitarian intervention were legitimized as Responsibility to Protect $\left(\mathrm{R}_{2} \mathrm{P}\right)$ by all Member States of the United Nations at the 2005 World Summit. When a state that is not protecting its own citizens against the most egregious and violent crimes - such as genocide, crimes against humanity, war crimes, and ethnic cleansing - states or multilateral organizations should intervene militarily with the support of the United Nations. Humanitarianism and $\mathrm{R}_{2} \mathrm{P}$ have been controversial issues in the literature and in the international community. ${ }^{2}$ The point of contention often revolves around the moral dilemma between respecting the right of political communities to decide on their own political life (as epitomized by the sovereignty norm) and whether or not humanitarianism should drive the policies of humankind, even if this means that certain polities' right to autonomy must be suspended.

In cases where certain norms such as sovereignty or humanitarianism/ human protection are contested, which norm eventually "wins" is partly to do with the persuasiveness of the argument, ${ }^{3}$ but it is also an undeniable fact that the global power balance is often influential in making some norms "matter" or more prevalent. It is no coincidence that liberal norms were considered the only game in town following the collapse of the Soviet Union, the ending of the Cold War, and the subsequent period of US unipolarity. But this power dynamic may be changing. The People's Republic China (PRC), which has traditionally jealously guarded its sovereignty and expressed deep misgivings about the moral justifications of intervention, ${ }^{4}$ is touted to become the next challenger to the hegemony of the United States, and that of Western dominance more broadly. ${ }^{5}$ In recent years, it has increasingly sought to position itself as a norm maker rather than a passive norm taker. What are the implications of China's rise for the future of humanitarian intervention? Given that changes in the global power balance can have a profound effect on the normative fabric of the international community, it seems important to explore this empirical question.

1 Jones 1995 .

2 Finnemore 2004; Moravcova 2014; Paris 2014; Crossley 2018; Grover 2018.

3 See Risse 2000.

4 For a classic statement on this, see Kim 1979, 414-415. For a broader overview, see Carlson $2005,30-33$. A good statement of the PRC's stance toward sovereignty and $\mathrm{R}_{2} \mathrm{P}$ is available in Luo 2014 .

5 Layne 2012. 
This article thus aims to make a contribution to this question by examining China's recent actions regarding UN decisions on the war in Syria from 2011 to 2018 . This relatively long period allows us to analyze how an actor is influenced by different norms when it makes decisions at the United Nations. China's opposition to UN resolutions has led to widespread condemnation by Western leaders. Behind this is an underlying fear that Beijing may use its newly found political power to undermine humanitarian norms in the international community. In 2012, US secretary of state Hillary Clinton called the UN Security Council veto a "travesty." ${ }^{6}$ In 2016, the British permanent representative to the UN, Matthew Rycroft, was particularly damning of China. He stated that it had "chosen to side with a party to the conflict which was aiding a despot who would allow his country to be reduced to rubble." In 2017, US ambassador to the UN, Nikki Haley, said, "Russia and China made an outrageous and indefensible choice today. They refused to hold [Syrian president] Bashar Al-Assad's regime accountable for the use of chemical weapons ... They put their friends in the Al-Assad regime ahead of our global security." And Rycroft added, "They have undermined the credibility of the Security Council and of the international rules preventing the use of these barbaric weapons." 8

Yet China's position on Syria has been far more ambiguous than what these critics claim. China seems to have changed its position on Syria at the Security Council between 2011 and 2018. While it may have started by being a veto power, it has since oscillated between concerns for Syrian sovereignty and taking a more responsible position on Syria. So, how, and especially why, has the PRC's position on humanitarian intervention evolved? Has it, as some critics have alleged, returned to its default "conservative" position of defending sovereignty on Syria? What are the implications for the future of intervention?

In this article, we draw broadly on constructivist insights on international relations, and take the view that a state's identity informs its interests. The article proceeds as follows to shed some light to these questions. First, drawing on China's past behavior in cases where humanitarian intervention took place, we show how China's evolving views on sovereignty, and its desire to have a voice in the international community through norm making have conditioned its cautious support for humanitarian intervention. We argue that since the mid-199os, China's attitude toward humanitarian intervention has become ambiguous and contradictory. There remains a certain degree of ambivalence, particularly when the PRC's sovereign integrity is at stake. Yet Beijing's stance

6 Abramovitch 2012.

7 UN 2016a.

8 “Syria Crisis: Hillary Clinton Calls UN Veto “Travesty” "2012; UN 2016b, at 6; UN 2017a, 4, 5. 
on diplomacy and intervention no longer depends exclusively on the concept of sovereignty, but takes into account concerns for humanitarian catastrophes.

Second, we aim to show that while China has at times prevented the Security Council from threatening sanctions on Syria, it has not necessarily denied that a humanitarian crisis exists, and that this was a legitimate concern for the international community. Third, we show that beyond conventional understandings of China's ambiguous positions at the UN, China is beginning to act more as a norm maker than norm taker. Instead of taking as given the interpretation of $\mathrm{R}_{2} \mathrm{P}$ by Western actors, China is offering its own vision of humanitarian intervention; that is, "responsible protection." China concentrates, within the UN framework, on mediation and being cautious facing the difficult situation in Syria, on the importance of protecting people, especially against the use of chemical weapons, and on the reconstruction of the Syrian political system and economy. The PRC remains sensitive to global humanitarian norms, and has actually acted more in favor of humanitarian intervention than its critics may claim.

\section{Creating the Conditions for China's Cautious Support for Humanitarian Intervention}

\subsection{Sovereignty, an Evolving Concept}

China has often been considered a staunch defender of the nonintervention norm. The reasons for this are partly ideological. China's own experiences of Western and Japanese imperialism mean that it has been uncomfortable with intervention that is led by the West. As Samuel S. Kim observed, "The 'protective' thinking enveloped in the Chinese obsession with sovereignty reflects a measure of the immense weight of past grievances." ${ }^{\prime 9}$ China has also developed a keen sense of smell for hypocrisy — and there are admittedly many cases of this - where the West blatantly fails to intervene in nondemocratic states with pro-Western leaders. ${ }^{10}$ The Chinese government has thus frequently expressed suspicion that $\mathrm{R}_{2} \mathrm{P}$ could be used by the West cynically as a fig leaf for overthrowing regimes that the latter does not like, and has been reluctant to make any direct contributions to intervention that lacks UN authorization. Writing in 1993, Liu Wenzong was adamant in his view that "using human rights to deny sovereignty is something that one can never accept."11 Twenty-one years

$9 \quad$ Kim 1979, 414. Also see Gong 1984; Suzuki 2009.

$10 \quad$ Ruan 2012.

11 W. Liu 1993, 38. 
later, Luo Yanhua was also repeating that "China is opposed to Western arguments that "human rights trump sovereignty." 12 It is therefore no wonder that "the claim that China's position on sovereignty has been relatively static and unyielding ... has become so widely accepted that it passes for conventional wisdom."13

However, China's views on sovereignty and nonintervention have not been static, even though this is not to deny the strong attachment to traditional interpretations of sovereignty. One key turning point for the PRC's interpretation of sovereignty was China's policy of "reform and opening up" which began in the 198 os and aimed at boosting economic growth through integrating China with the global economy. This policy resulted in China's gradual participation in a growing number of international regimes, which often entailed China's partial surrender of its sovereign prerogatives to outside forces (China's joining of the World Trade Organization, which restricts Beijing's ability to freely formulate its trade and tariff policies, is a case in point). These changes have been hugely beneficial for China's development, rather than being detrimental. As a result, Beijing no longer subscribes to the view that absolute sovereignty is needed to protect Chinese national interests. ${ }^{14}$

China's increased integration into the international community has also resulted in a greater interaction with the global human rights regime. Since the mid-199os, the need to the counter "China threat" thesis in the West, combined by a greater desire to be seen as a great power has prompted China to play—or at least be seen to be playing — a part in maintaining global peace and order. ${ }^{15}$ While its own human rights record leaves much to be desired, it has to a certain degree internalized the importance of human rights norms. ${ }^{16}$ As a consequence, Beijing no longer contests fully the notion that certain human rights issues are a legitimate concern for the global community, rather than an exclusively domestic matter.

This shifting stance was visible as early as 1991, when Beijing published its first White Paper on human rights. The Preface noted, "The issue of human rights has become one of great significance and common concern in the world community."17 A considerable number of Chinese analysts now agree that sovereignty is an evolving concept, and that contemporary sovereignty "should

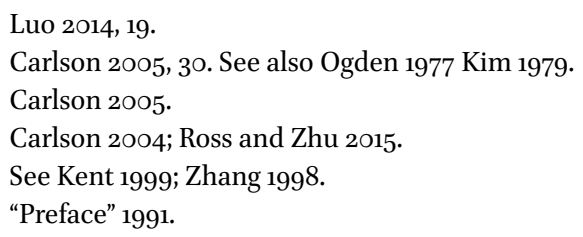


be linked with human rights, as well as multifaceted factors that include political, economic and social security."18 This growing flexibility is one of the key reasons for Beijing's acquiescence to $\mathrm{R}_{2} \mathrm{P}$, which some Chinese analysts believe is a concept that "could be used to bridge the divide between supporters of 'humanitarian intervention' and supporters of state sovereignty and nonintervention."19 China, for sure, did voice its concern that "so-called humanitarian justifications are applied inconsistently and used as window dressing to justify illegitimate interference" to the International Commission on Intervention and State Sovereignty. ${ }^{20}$ The Chinese thus insisted that authorization to use force for "humanitarian" reasons had to be given by the Security Council, and that consent from the host state was crucial. Yet at the 2005 World Summit, it "did little to obstruct the Summit's endorsement of RtoP [R2P], under the proviso that it would affirm the authority of the UN Security Council and refrain from including criteria or guidelines for military action."21

Beijing's shifting stance is also apparent from its security policies, and these changes broadly reflect its gradual acceptance that sovereignty is not absolute, as well as its growing desire to counter its negative image as a threat to global order, both of which took place in the early and mid-199os..2 Even before states accepted the concept of $\mathrm{R}_{2} \mathrm{P}$ at the UN World Summit in 2005, China's change was visible. During NATO's Kosovo campaign in 1999, the Chinese argued that the "settlement of the Kosovo issue should be based on respect for the sovereignty and territorial integrity of the Federal Republic of Yugoslavia," and such critical voices became prominent in the context of the NATO bombing of the Chinese embassy in Belgrade. ${ }^{23}$ However, in the same it year, "Beijing played a quiet, supportive role in facilitating humanitarian intervention in East Timor."24 It agreed to Security Council Resolutions 1264 and 1272, which authorized the deployment of multinational forces to restore peace in East Timor, and established a UN Transitional Administration in East Timor.

Since then, the PRC has broadly continued its policy of cautious support of intervention. While continuing to pay rhetorical lip service to the principle that the host state's consent is always required prior to intervention, it has

\footnotetext{
18 Y. Wang 2001, 144. See also Carlson 2006 and Davis 2011.

19 Pang Zhongying, as quoted in Foot and Walter 2011, 6o.

20 Teitt 2011, 300. Such concerns can be found in Zhu 2001.

21 Teitt 2011, 303.

22 Carlson 2005.

23 Remarks made by Qin Huasun, China's representative to the UN, emphasis added. See UN 1999, 12.

24 Carlson 2005, 176.
} 
allowed itself some political space for maneuver. While Beijing has not yet participated in any military interventions, it has become a key contributor to UN Peacekeeping Operations (UNPKO). ${ }^{25}$ China's behavior with regard to policies toward several conflicts has changed. The PRC abstained from or agreed with the use of Chapter VII in the cases of Somalia, the Balkans, Iraq, Afghanistan, East Timor, Sierra Leone, Côte d' Ivoire, Sudan, Libya, Central African Republic, and Mali. ${ }^{26}$

In the case of Sudan, China played an important role in obtaining President Omar al-Bashir's somewhat reluctant "consent" for accepting the UNAfrican Union peacekeeping mission. ${ }^{27}$ It did not veto Resolution 1706 in 2006, whereby the UN peacekeeping operation would be deployed in Darfur to protect civilians under a Chapter VII mandate. This is an indication that China does not insist on a strict, more normative/political definition of consent, which must be given under perfect conditions of freedom. Rather, Beijing's stance on this issue is a more legalistic one, in that intervention can be justified as long as the host state has-regardless of its actual preferences—given its "permission" on paper. Whether or not this was given under conditions of pressure or coercion is a matter of secondary concern.

These changes in Beijing's behavior are again difficult to explain without reference to normative factors. China's close relations with Khartoum were coming under increasing criticism by 2006. ${ }^{28}$ The fact that China found itself unable to veto Resolution 1706 - despite China's strategic interests in Sudanese oil and the risk of incurring the Sudanese government's displeasure-is a strong indication that Beijing recognized that there did exist a humanitarian crisis in Sudan, as well as its awareness that being seen as opposing efforts to save human lives was likely to earn it a negative international reputation. ${ }^{29}$ It is worth noting that attempts at "shaming" can be successful only if the party that is "shamed" shares similar notions of what behavior is morally or socially "unacceptable." The fact that China balked at the idea of being shamed for siding with regimes that harmed their own citizens is evidence of its gradual internalization of certain human rights norms. Its refusal to use its veto also "suggests that many Chinese elites have now come to accept the general legitimacy of multilateral intervention to resolve particularly prominent humanitarian crises."30

\footnotetext{
$25 \quad$ Hirono and Lanteigne 2011.

26 Gegout 2018.

27 Brautigam 2009, 282-283.

28 "China Envoy Defends Africa Policy" 2006.

29 A similar point has been made with reference to the intervention in Libya and the adoption of UN Security Council Resolution 1970 in 2011. See Bellamy and Williams 2011, 844. 
Even in the case of Libya-nowadays cited as an event that made the Chinese take a more hard-line attitude toward the West with regard to the Syrian civil war-Beijing's initial position was not necessarily characterized by opposition. ${ }^{31}$ China did not want to be made a scapegoat (beiheiguo) for potential inaction, and risk a loss to its international reputation. ${ }^{32}$ This is again testimony to the fact that Beijing is acutely aware of human rights norms and its links to international legitimacy, and is not necessarily going to sacrifice civilian lives on the ideological altar of sovereignty.

\subsection{Norm Making in Humanitarian Intervention: "Responsible Protection"}

Interestingly, this partial acceptance of humanitarian intervention has continued despite China's alleged "assertive turn" since the start of the 2010s. While much of the recent discussions on China's "assertiveness" have concentrated on the territorial disputes in the East and South China Sea, another aspect of this development is China's attempts to become a norm maker rather than a norm taker. This policy is linked to the PRC's desire to have its voice in global governance heard more in a way that is commensurate with its newly found political power. Since China found itself facing global condemnation after the Tiananmen Massacre in 1989, its main foreign policy strategy has been "taoguang yanghui," which was essentially concerned with keeping a low profile and not seeking leadership. However, this famous sentence is incomplete; in full, it is "taoguang yanghui, yousuo zuowei," which can be translated as "keeping a low profile, but trying nevertheless to accomplish something." Since the beginning of the 2010s, Beijing's emphasis has arguably shifted gradually to yousuo zuowei, and there have been increasing debates about how China can (and should) use its newly found influence in the international community. One of the best known of these attempts is, of course, the Asia Infrastructure Investment Bank and the Belt and Road Initiative, which aims to increase China's economic and political influence within Asia, and more broadly the world. ${ }^{33}$

It is arguable that the Chinese have also begun to do this in the area of humanitarian intervention, which has been named "responsible protection" 34

\footnotetext{
31 "China's Stake in Syria Stand-Off" 2012.

32 Interview, Chinese Academy of Social Science, Beijing, 1 November 2011.

33 A useful discussion on this topic can be found in H. Wang 2014.

34 "Responsible protection" has been forwarded by Ruan Zongze, who is a well-known analyst at the Chinese Institute of International Studies, a think tank affiliated with the Ministry of Foreign Affairs. Given the close relation the institute enjoys with the political decisionmakers, as well as the political costs of departing from political orthodoxy
} 
This concept consists of six pillars. First, the object of protection must be "the people of the target country and peace and stability of the relevant region ... not specific political parties or armed forces." Second, the Security Council should be the "only legitimate actor to perform" the duty of protection. Third, intervention should be the last resort, and non-military means should prevail as they "produce long-lasting results with lesser side effects." Fourth, protection should not create "greater humanitarian disasters" or be used for regime change. Fifth, the 'protectors' "should be responsible for the post-'intervention' and post-'protection' reconstruction of the state concerned." Finally, the UN should "establish mechanisms of supervision, outcome evaluation and post fact accountability to ensure the means, process, scope and results of 'protection." 35 In some respects, the proposals for responsible protection reflect long-standing Chinese principles, such as the need for Council legitimation and Council-backed operations to be the sole "legitimate" force for intervening. This is of course nothing new, and stem from China's long-standing suspicion of the possibility that $\mathrm{R}_{2} \mathrm{P}$ could be abused by powerful states to implement regime change, as well as its commitment toward the norm of sovereignty. It is also indicative of Beijing's ongoing reluctance to fully commit itself to the causes of the great powers - in practice, the Western powers.

However, it would be premature to dismiss the concept of responsible protection as part of "a broader effort to remake the rules of the international system or perhaps free itself from their constraints." ${ }^{36}$ The concept does not necessarily deny the use of force-it merely states it should be the last resort. This is again indicative that the Chinese political elite recognizes that certain humanitarian catastrophes could merit military intervention. This line has also been repeated by the Chinese diplomat who stated in 2013 that $\mathrm{R}_{2} \mathrm{P}$ should be adopted on the basis of case-by-case analysis. ${ }^{37}$ In addition, it is important to note that other aspects of responsible protection are partly echoed by nonChinese analysts as well. This makes it more difficult to dismiss this concept as merely a Chinese smokescreen to undermine intervention, as epitomized by $\mathrm{R} 2 \mathrm{P}$. With regard to a preference for diplomacy rather than military interven-

in a party-state like the PRC (particularly since the Xi Jinping era), Ruan's views can be assumed to be ideas that have been articulated among elite circles. Furthermore, the fact that this article has been disseminated for an international audience in English is also indicative of Beijing's desire to demonstrate its readiness to act as a responsible great power.

35 Ruan 2012.

36 Swaine 2010, 3 .

37 T. Liu and Zhang 2014, 420. 
tion to reduce the number of casualties, ${ }^{38}$ Alex Bellamy takes a similar stand to the Chinese position, as he argues that $\mathrm{R}_{2} \mathrm{P}$ should be used only as a last resort, and actors should focus on preventive diplomacy. ${ }^{39}$ It is also noteworthy that the call for "postprotection" responsibility bears conspicuous similarity to the doctrine of "responsibility to rebuild," meaning that interveners in $\mathrm{R}_{2} \mathrm{P}$ situations should make "a genuine commitment to helping to build a durable peace, and promoting good governance and sustainable development," which was originally introduced into the $\mathrm{R} 2 \mathrm{P}$ concept by the International Commission on Intervention and State Sovereignty in 2001. ${ }^{40}$

If we are to accept that China's simultaneous commitment to the principle of sovereignty and growing awareness that humanitarian catastrophes may justify intervention in some cases has - despite its growing "assertiveness"continued to this day, then it is worth examining how this has manifested itself in recent controversies around humanitarian crises. To this end, we now turn to the Syrian case.

China on Syria: Navigating the Tension between Sovereignty and Humanitarian Concerns

China's recent stance in Syria shows an ambiguous commitment to humanitarian intervention (see Table 1). In 2011, China (with Russia) vetoed a draft resolution that would have threatened sanctions, emphasizing that Syria's sovereignty needed to be respected. ${ }^{41}$ Beijing continued to invoke sovereignty in 2012. In February 2012, Beijing joined Moscow in vetoing a draft resolution that called on both sides of the conflict to end violence. Crucially, this veto was cast despite the fact that the resolution did not authorize any form of international intervention. Li Baodong, the representative of the PRC, stated that while the "international community should provide 'constructive assistance'" to end the violence in Syria, "the country's sovereignty, independence and territorial integrity must be respected." 42 Between December 2016 and February 2017, China adopted a conservative line on Syria again. Even though China supported access to civilians for humanitarian assistance (Resolutions 2328 and 2332), and international efforts for negotiations (Resolution 2336), it followed

\footnotetext{
$3^{8}$ Garwood-Gowers 2013; T. Liu and Zhang 2014.

39 Bellamy 2011.

$40 \quad$ Paris 2014, 577.

$41 \mathrm{UN} 2 \mathrm{O11}$.

$42 \mathrm{UN} 2 \mathrm{O} 2$.
} 
TABLE 1 China's voting pattern in UN resolutions concerning Syria ${ }^{a}$

\begin{tabular}{|c|c|c|c|c|}
\hline $\begin{array}{l}\text { Date and } \\
\text { resolution }\end{array}$ & Aim of the resolution & $\begin{array}{l}\text { China's } \\
\text { position }\end{array}$ & $\begin{array}{l}\text { China respects } \\
\text { humanitarian } \\
\text { principles }\end{array}$ & $\begin{array}{l}\text { Draft resolution or } \\
\text { resolution infringes } \\
\text { on sovereignty }\end{array}$ \\
\hline $\begin{array}{l}\text { 2011, Draft } \\
\text { Resolution } \\
\text { S/2011/612 }\end{array}$ & Threaten sanctions & $\begin{array}{l}\text { Veto (with } \\
\text { Russia) }\end{array}$ & No & No \\
\hline $\begin{array}{l}\text { Early 2012, } \\
\text { Draft Resolu- } \\
\text { tion S/2012/77 }\end{array}$ & Ask for end of violence & $\begin{array}{l}\text { Veto (with } \\
\text { Russia) }\end{array}$ & No & No \\
\hline $\begin{array}{l}\text { Late } 2012 \text {, Draft } \\
\text { Resolution } \\
\mathrm{S} / 2012 / 53^{8}\end{array}$ & $\begin{array}{l}\text { Threaten sanctions (with a } \\
\text { mention of Chapter VII) }\end{array}$ & $\begin{array}{l}\text { Veto (with } \\
\text { Russia) }\end{array}$ & No & $\begin{array}{l}\text { No (but possible } \\
\text { in the long term, } \\
\text { as Chapter VII is } \\
\text { mentioned) }\end{array}$ \\
\hline $\begin{array}{l}\text { 2013, Resolu- } \\
\text { tion } 2118\end{array}$ & $\begin{array}{l}\text { Ensure the elimination of the } \\
\text { Syrian chemical weapons pro- } \\
\text { gram }\end{array}$ & $\begin{array}{l}\text { Unanimous } \\
\text { support }\end{array}$ & Yes & $\begin{array}{l}\text { Resolution states } \\
\text { it is committed to } \\
\text { sovereignty }\end{array}$ \\
\hline $\begin{array}{l}\text { 2014, (three) } \\
\text { Resolutions } \\
2139,2165,2191\end{array}$ & Deliver humanitarian support & $\begin{array}{l}\text { Unanimous } \\
\text { support }\end{array}$ & Yes & No \\
\hline $\begin{array}{l}\text { 2014, Draft } \\
\text { Resolution } \\
\text { S/2014/348 }\end{array}$ & $\begin{array}{l}\text { Refer Syria to the International } \\
\text { Criminal Court (with a mention } \\
\text { of Chapter VII) }\end{array}$ & $\begin{array}{l}\text { Veto (with } \\
\text { Russia) }\end{array}$ & No & Yes \\
\hline $\begin{array}{l}\text { 2015, (four) Res- } \\
\text { olutions } 2209 \text {, } \\
2235,2254,225^{8}\end{array}$ & $\begin{array}{l}\text { Require the prohibition of chlo- } \\
\text { rine gas; } \\
\text { create the Joint Investigative } \\
\text { Mechanism for investigating } \\
\text { the use of chemical weapons; } \\
\text { ask for a Road Map for Peace; } \\
\text { ask for cross-border aid delivery }\end{array}$ & $\begin{array}{l}\text { Unanimous } \\
\text { support }\end{array}$ & $\begin{array}{l}\text { Yes } \\
\text { Yes }\end{array}$ & $\begin{array}{l}\text { No }^{b} \\
\text { No }\end{array}$ \\
\hline $\begin{array}{l}\text { 2016, Draft } \\
\text { Resolution } \\
\text { S/2016/846 }\end{array}$ & $\begin{array}{l}\text { Urge for cessation of hostilities, } \\
\text { and end of bombardments over } \\
\text { Aleppo }\end{array}$ & $\begin{array}{l}\text { Abstention } \\
\text { (whereas Rus- } \\
\text { sia vetoed) }\end{array}$ & Yes & $\begin{array}{l}\text { Yes (acknowledged } \\
\text { by China) }\end{array}$ \\
\hline $\begin{array}{l}\text { 2016, Draft } \\
\text { Resolution } \\
\text { S/2016/1026 }\end{array}$ & End the attack of Aleppo & $\begin{array}{l}\text { Veto (with } \\
\text { Russia) }\end{array}$ & Yes & Yes \\
\hline $\begin{array}{l}\text { 2016-2017, } \\
\text { (seven) Resolu- } \\
\text { tions } 2268,2314, \\
2319,2328,2332, \\
2336(2016), \\
2393(2017)\end{array}$ & $\begin{array}{l}\text { Allow access to civilians for } \\
\text { humanitarian assistance; }\end{array}$ & $\begin{array}{l}\text { Unanimous } \\
\text { support }\end{array}$ & Yes & No \\
\hline
\end{tabular}


TABLE 1 China's voting pattern in UN resolutions concerning Syria ${ }^{\mathrm{a}}$ (cont.)

\begin{tabular}{|c|c|c|c|c|}
\hline $\begin{array}{l}\text { Date and } \\
\text { resolution }\end{array}$ & Aim of the resolution & $\begin{array}{l}\text { China's } \\
\text { position }\end{array}$ & $\begin{array}{l}\text { China respects } \\
\text { humanitarian } \\
\text { principles }\end{array}$ & $\begin{array}{l}\text { Draft resolution or } \\
\text { resolution infringes } \\
\text { on sovereignty }\end{array}$ \\
\hline & $\begin{array}{l}\text { call for an international effort } \\
\text { (political talks, and UN access } \\
\text { to Aleppo) }\end{array}$ & & Yes & No \\
\hline $\begin{array}{l}\text { 2017, Draft } \\
\text { Resolution } \\
\text { S/2017/172 }\end{array}$ & $\begin{array}{l}\text { Condemn the use of chemical } \\
\text { weapons (with a mention of } \\
\text { Chapter VII) }\end{array}$ & $\begin{array}{l}\text { Veto (with } \\
\text { Russia) }\end{array}$ & No & Yes \\
\hline $\begin{array}{l}\text { 2017, Draft } \\
\text { Resolution } \\
\text { S/2017/884 }\end{array}$ & $\begin{array}{l}\text { Prolong/renew mandate of } \\
\text { international body on the use } \\
\text { of chemical weapons }\end{array}$ & $\begin{array}{l}\text { Abstention } \\
\text { (whereas Rus- } \\
\text { sia vetoed) }\end{array}$ & Yes & No \\
\hline $\begin{array}{l}2017 \text { and } 2018, \\
\text { Draft Resolu- } \\
\text { tions } S / 2017 / 315 \\
\text { and } S / 2018 / 3^{21}\end{array}$ & $\begin{array}{l}\text { Condemn the use of chemical } \\
\text { weapons, and ask for account- } \\
\text { ability for criminals }\end{array}$ & $\begin{array}{l}\text { Abstention } \\
\text { (whereas Rus- } \\
\text { sia vetoed) }\end{array}$ & Yes & No \\
\hline $\begin{array}{l}2018, \text { Resolu- } \\
\text { tions } 2401 \text { and } \\
2449\end{array}$ & $\begin{array}{l}\text { Ask for humanitarian access; } \\
\text { ask for a cessation of hostilities }\end{array}$ & $\begin{array}{l}\text { Unanimous } \\
\text { support }\end{array}$ & $\begin{array}{l}\text { Yes } \\
\text { Yes }\end{array}$ & $\begin{array}{l}\text { No } \\
\text { No }\end{array}$ \\
\hline
\end{tabular}

\section{Notes:}

a. The discussion of UN Security Council resolutions does not include those on the creation of UN Supervision Mission in Syria, which suspended its activities in 2012, and on the condemnation of terrorism, as these do not infringe on the concept of sovereignty.

b. Syria became a party to the Chemical Weapons Convention in the fall of 2013 .

Russia again when it vetoed a resolution that would have had all parties in Syria end attacks on the city of Aleppo within twenty-four hours for a duration of at least one week.

China's frequent invoking of the sovereignty norm, coupled with its allegedly more "assertive" foreign policy in recent years, seems to have prompted analysts to resurrect the "conventional wisdom" that the PRC has always been the staunchest guardian of the sovereignty norm, and is happy to sacrifice humanitarian concerns for national interests. ${ }^{43}$ A typical example of this is a British journalist's claim that "China's diplomacy is not at all about principles and protecting civilians in a far-off nation, but about hard-headed self interest," even though "civilians are continuing to die in Syria in their dozens." 44

\footnotetext{
43 Swaine 2010, 3.

44 "China's Stake in the Syria Stand-Off" 2012.
} 
These arguments, however, run into problems when faced with the voting patterns of Beijing regarding Syria, which are best depicted as indeterminate, with agreements and abstentions. ${ }^{45}$ For a start, the Chinese have not been in a state of denial, and insisted that the civil war is purely a domestic issue for the Syrians to solve themselves. As one Chinese analyst noted, the "military conflicts in Syria have caused significant civilian casualties, a fact that should attract the attention of the international community." ${ }^{16}$ In 2013, China also supported Security Council Resolution 2118 on Syria, which aimed to secure and destroy Syria's chemical weapons stockpile. Chinese foreign minister Wang Yi did not mention the issue of sovereignty. Instead, he stated, "[The Council] must maintain a sense of responsibility towards the Syrian people and to world history and ensure that any decision it takes is able to pass the test of history."47 He referred to China's own experience of chemical weapons during World War II. In 2015, despite Wang Yi's statement that "Syria's future must be decided by Syrians, consistent with the principles of the United Nations Charter and international law,"48 China agreed with other Security Council members that the use of chlorine gas should be prohibited, and a mechanism of investigation should be created (Resolutions 2209 and 2235).

In 2016, China abstained while Russia vetoed Security Council Draft Resolution 846. The Chinese representative to the UN, Liu Jieyi, said the international community had to "keep its focus on achieving a political solution through dialogue," and "the Security Council should help improve the situation, help push for a cessation of hostilities." But he also acknowledged that the resolution did "not reflect full respect for Syria's sovereignty and independence."49

In February 2017, the PRC blocked a Security Council resolution that would have sanctioned Syria for using chemical weapons against its citizens. This was to be a temporary veto on the issue of chemical weapons. China said that investigations on chemical weapon were still ongoing, so the resolution was too early, and that "every Council member bears the sacred responsibility of maintaining international peace and security." ${ }^{50}$ Yet two months later, it changed its position again: it abstained, but condemned the reported chemical weapons attack on the Syrian town of Khan Shaykhun, and wanted to hold the perpe-

\footnotetext{
$45 \quad$ Fung 2018.

46 Qu 2012, 17, emphasis added.

47 UN 2013, 9, emphasis added.

48 Tiezzi 2015.

49 UN 2016a.

$5^{\circ} \quad$ UN 2017a, 10.
} 
trators accountable. ${ }^{51}$ In April 2018, China abstained again when a resolution would have condemned the use of chemical weapons. It reiterated the importance of sovereignty, but also the importance of negotiations and of the prohibition of the use of chemical weapons. ${ }^{52}$

Understanding China's Evolving Politics in Syria: Ambiguity, with a Growing Support for Responsible Protection

\subsection{The Limits of Conventional Understanding}

China's voting behavior in the UN with regard to Syria defies simplistic generalizations. Some analysts have argued that "China along with Russia, both authoritarian states themselves, are concerned about the way repressive regimes have been falling in the Arab Spring." ${ }^{\prime 53}$ This argument essentially states that China is opposing humanitarian intervention because it somehow feels a sense of "authoritarian solidarity" and fears regime change. This claim is problematic. Beijing may fear regime change within its own borders, but as long as China's own national interests (regime/state survival and economic growth) are not affected, it has not actively sought to prop up other authoritarian rulers for the sake of an ideological commitment to undemocratic rule. Indeed, China has seen a number of authoritarian states democratize in recent years (examples include Indonesia), but it has not necessarily tried to block this process. Instead, China has tended to watch from the sidelines.

Other researchers have said that China could be wary of Islamism to protect its security. Beijing fears that radical Islamism "could end up spreading ... to China's own Muslim populations in Xinjiang." 54 With the PRC's oppressive policies toward its Muslim minority (such as the incarceration of Muslims and forced "Sinicization") in Xinjiang recently placed under the spotlight, the Chinese government could fear a potential backlash from radical Islamic groups within its borders. While fears of radical Islamic militants infiltrating China is certainly a possibility, it is debatable as to whether or not this is "enough to shape its whole policy towards Syria." 55

\footnotetext{
$51 \quad \mathrm{UN} 2 \mathrm{O} 17 \mathrm{~b}$.

52 UN 2018.

53 "China's Stake in the Syria Stand-Off" 2012. On cooperation among authoritarian regimes, see Schoen and Kaylan 2014; von Soest 2015.

54 "China's Stake in the Syria Stand-Off" 2012.

55 "China's Stake in the Syria Stand-Off" 2012.
} 
It is possible that pragmatic concerns motivate the Chinese leadership. A likely interest for China in 2017 was to show "its goodwill and willingness to work with the US on global issues." 56 This is consistent with the PRC's goal of gaining acceptance as a responsible great power and countering the various "China threat" theses, which have been ongoing since the late 199os. China does not have economic and political interests in Syria like it did in Libya. As one Chinese scholar notes, in 2010 Syria accounted "for only $0.08 \%$ of China's overall trade," and was worth a meager $\$ 2.48$ billion. ${ }^{57}$ However, China has strong economic interests in the Middle East. It needs to keep good relations with Syria's neighbors, and over 44 percent of Chinese imports of oil came from the Middle East in 2018. ${ }^{58}$ As early as November 2017, China has wanted to include Syria in its Belt Road Initiative. ${ }^{59}$ In 2018, Xi Jinping pledged that China would provide $\$ 20$ billion in loans to help Arab states in economic reconstruction. ${ }^{60}$

\subsection{China's Contribution to Humanitarianism through Responsible Protection}

More importantly, however, China's indeterminacy in the Syria crisis also reflects its gradual acceptance of humanitarianism driving UN polices. On the one hand, the PRC has continued to demonstrate elements of conservatism with regard to upholding the sovereignty norm. In 2012, 2014, and 2017, China vetoed all Security Council resolutions that referred to $\mathrm{R}_{2} \mathrm{P}$ through Chapter VII. ${ }^{61}$ On the other hand, the PRC's voting patterns in 2013 and 20172018 were indicative of the fact that there were moral limitations for Beijing's defense of sovereignty. The fact that the PRC went along with resolutions that called for the restrictions of Syria's use of chemical weapons shows its awareness of this normative constraint and sensitivity to be seen as a responsible actor within international society. ${ }^{62}$ It did not consider the Bashar al-Assad regime's use of chemical weapons in a civil war as a domestic issue, where sovereignty needed to be upheld.

China's repeated statements that the humanitarian crisis in Syria was a matter of international concern suggests that the latter was an important part of Beijing's reasoning. China's UN representative, Li Baodong, did not deny

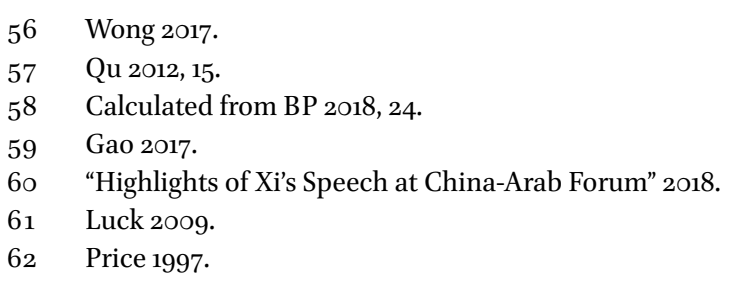


the existence of a humanitarian problem, and neither did his invoking of the sovereignty norm mean that the international community should leave the Syrians to sort out their civil war by themselves. ${ }^{63}$ Crucially, China's disquiet over the efficacy of intervention was not entirely out of sync with other Western powers, despite their condemnation of China's behavior. Both US and British military personnel are reported to have expressed their concerns about intervention, stating the "potential for killing vast numbers of civilians and plunging the country closer to civil war." 64

Some Chinese principles as articulated in the responsible protection concept could also have influenced some of Beijing's voting behavior. For instance, the PRC's caution toward regime change may, on the surface, look like a more conservative concern that fears that the West may abuse its power to overthrow any anti-Western government. Yet this could also be interpreted as the Chinese following their principle in the responsible protection that the "purpose of 'protection must be defined," and not go beyond its mandate of what it was supposed to protect in the first place. There are some real justifications for this concern. Humanitarian intervention or $\mathrm{R}_{2} \mathrm{P}$ is vulnerable to abuse, as powerful states with access to sufficient military and other material resources can intervene when and where they choose. ${ }^{65}$

However, this does not mean a rigid adherence to nonintervention. As Qu Xing of the China Institute of International Studies notes, if regime change takes place in a multilateral setting, rather than because of hegemonic interests (in practice, Western interests), the PRC may not always stand in the way. This again highlights the need to exercise caution in dismissing Beijing's motives as being concerned solely with challenging the Western-dominated international order, or eroding humanitarian intervention norms. As Qu notes with reference to Syria:

If the LAS [League of Arab States] can reach an agreement with all parties concerned in Syria so that Bashar will transfer power ... China would have no difficulty endorsing such a decision since China welcomes any political arrangement supported by all sides in Syria. ${ }^{66}$

With regard to the PRC's claim that responsible protection should take into account the possibility that intervention could bring greater casualties, this line

63 Permanent Mission of the People's Republic of China to the UN 2012.

64 US and British military personnel, as quoted in Paris 2014, 587.

65 Gegout 2018, 32.

66 Qu 2012, 19. 
was visible in some of its urging caution against intervention. However, China's repeated statements that the humanitarian crisis in Syria was a matter of international concern suggests that the latter was also an important part of Beijing's reasoning. China's UN representative from 2010 to 2013, Li Baodong, did not deny the existence of a humanitarian problem, and neither did his invoking of the sovereignty norm mean that the international community should leave the Syrians to sort out their civil war by themselves. ${ }^{67}$ Crucially, China's disquiet over the efficacy of intervention was not entirely out of sync with other Western powers, despite their condemnation of China's behavior. ${ }^{68}$

Chinese concerns about responsible "postprotection" are also a strong possibility that motivated their cautious attitude toward intervening in Syria. Chinese analysts have taken note of the sectarian violence that erupted in Iraq after the US-led invasion, and have (with some justification) questioned whether this belief in the imposition of a "single model" of governance is the only way to bring peace and solve internal conflict—even though they may ultimately support it if such policies bring results. ${ }^{69}$

Overall, despite the claims that China has become more "assertive"-including in its support of the sovereignty norm - what we are seeing from China is a continuation of the same policies with regard to intervention. ${ }^{70}$ Defending "China's sovereignty" does remain "a paramount concern" and is likely to be opposed. ${ }^{71}$ Yet despite its boastful claims of China's rise, the PRC simultaneously remains sensitive to its international reputation. ${ }^{72} \mathrm{~A}$ flagrant disregard for humanitarian concerns would considerably damage the PRC's international image, and pose a setback for Beijing's quest to construct an identity of a responsible great power in the international system. ${ }^{73}$

\section{5}

\section{Conclusion}

China's engagement with humanitarian intervention $/ \mathrm{R} 2 \mathrm{P}$ is a complex one that does not necessarily reveal a consistent strategy on the part of Beijing. The

\footnotetext{
67 Permanent Mission of the People's Republic of China to the UN 2012.

68 Paris 2014, 587.

69 Interview, China Foundation for International Strategic Studies, Beijing, 23 April 2007.

70 Whether or not China's overall foreign policy has actually become "assertive" is a contested issue, however. For a critical discussion, see Swaine 2010; Johnston 2013; Jerdén 2014; Roy 2019.

71 Carlson 2005, 176.

72 See, for instance, Guo 2004; Yan 2006.

73 He and Feng 2012.
} 
Chinese have displayed a strong sense of disquiet toward the debates of international intervention in the case of Syria, which has unfortunately resulted in deadlock at the Security Council and further civilian deaths in the country. It seems, however, that too many Western politicians have been quick to point the finger of blame at the PRC, and denounce the latter for its lack of a sense of responsibility. To an extent, Beijing's own ambiguity has not helped matters. As an authoritarian party state with a dismal record of protecting its own citizens' human rights, it is easy — if not analytically complacent - to extrapolate from China's domestic political situation and claim that the PRC is indifferent to global humanitarian crises.

China's actual behavior has been more complex, however. In the case of Syria, China's stance can be seen to be related to important questions of what policies should be adopted by the international community to solve a humanitarian crisis, ${ }^{74}$ rather than simply opposing the West to prove its "assertiveness." The Chinese have not necessarily merely offered critiques of the current arrangements, but also have suggested a number of proposals to overcome these shortcomings. Far from overturning humanitarian intervention, China has provided some support to humanitarian policies in Syria. The 2016 Draft Resolution 846 was the most unexpected one, as it could have infringed on Syrian sovereignty. Although China once vetoed a resolution on the condemnation of the use of chemical weapons (but this resolution made a direct reference to Chapter VII), it did not veto any other resolution of the same type. Since 2011, China has offered its own vision of R2P: responsible protection. It has acknowledged the humanitarian necessity of addressing the conflict in Syria, and wants to focus on political dialogue. In early 2016, China invited the Syrian government and the opposition to Beijing for discussions. In March 2016, China appointed its first special envoy for Syria, Xie Xiaoyan. In August 2016, China said it would provide personnel training and humanitarian aid to Syrian president al-Assad. By doing so, it is showing its capacity of being a diplomatic actor in the Syrian crisis, and in the wider Middle East (with growing ties with Iran and Saudi Arabia), at a time when it is also showing its presence on the African continent.

Overall, this means that radical changes in current arrangements for humanitarian intervention are unlikely to be fundamentally undermined as China's rise to power continues. Ultimately, we need to remind ourselves that ambiguous, contradictory behavior is often "the stuff of politics." Beijing remains some-

74 This point was raised to one of the authors during the China Foundation for International Strategic Studies interview. 
what torn between its suspicions of intervention and the hegemonic power of the West (in particular, the United States) and its desire to move beyond a norm taker while simultaneously upholding its image as a responsible power. Unless its own sovereign prerogatives are at stake, it cannot afford to be completely indifferent to global norms that have been built up over the years and construct an alternative international order.

Beijing will continue to harbor its suspicions toward Western hegemonic ambitions, but it is not likely to oppose all cases of humanitarian intervention on principle. While it is true that the policy of "doing something" may result in the Chinese attempting to become norm makers in this area, what we have seen from China so far does not constitute a radical departure from the $\mathrm{R}_{2} \mathrm{P}$ principle. There will, of course, be confrontations between China and the West in the future. Humanitarian intervention is, however, a morally fraught issue where tensions and contradictions easily arise. ${ }^{75}$ Our research suggests that simplistic blaming of Chinese opposition to failures in Western proposals to intervene risk misreading Chinese intentions, and could only complicate the West's relations with China. It could also prevent the efficacious resolving of future humanitarian crises.

This does not meant that our research is complete. Due to the politically opaque nature of China's political decisionmaking structure, we have adopted a statist approach and "blackboxed" the domestic political bargaining process. Studies on informal politics in China indicate that "informal groups have become increasingly oriented ... to the promotion of policies designed to enhance their bureaucratic interests. ${ }^{76}$ This could lead one to hypothesize that moderate attitudes toward $\mathrm{R}_{2} \mathrm{P}$ are more likely to come from the Ministry of Foreign Affairs and its interest group, given that the ministry is at the forefront of China's diplomatic interactions, and could have an interest in promoting China as a "responsible," "status quo" power. Indeed, China's increasing involvement in UNPKO is attributed to the "institutional lead taken by the Ministry of Foreign Affairs with central leadership backing."77 One could also surmise that critical voices are likely to come from factions closer to the Peoples' Liberation Army (PLA), which has been depicted as "the hypernationalistic guardian of claimed Chinese territorial sovereignty."78 However, Alastair Iain Johnston has

\footnotetext{
75 Paris 2014.

76 Dittmer 1995. 34 .

$77 \quad$ Foot and Walter 2011, 58.

78 Shambaugh 1999-2000, 52. The PLA is reported to have been skeptical about participating in UNPKO, stating that this was not a particularly important issue in which the Chinese armed forces needed to be involved. See Foot and Walter 2011, 58 .
} 
noted that "no one really knows the working relationship between the top political leadership and the PLA, as one hears different versions in Beijing." ${ }^{29}$ In the future, a researcher with better access to Chinese government officials could explore how different actors understand the concept of responsible protection. Opening up the Chinese domestic blackbox would yield further fascinating insights into our understanding of Chinese domestic and foreign policy.

\section{Acknowledgments}

We are equal coauthors. Catherine Gegout thanks Ambassador Nicholas Burns and Professor Karl Kaiser for their support during her time as Pierre Keller Visiting Professor at Harvard Kennedy School, United States, in Spring 2019. She is also grateful for the support of Professor Ulrich Krotz and the Europe in the World research group at the Robert Schuman Centre, European University Institute in Firenze, Italy. Shogo Suzuki thanks Julian Junk and the participants at the Workshop on International Intervention, organized by the University of Konstanz in 2012. He also thanks James Pattison for valuable comments on a later draft of this article.

\section{Bibliography}

Abramovitch, Seth. "Hillary Clinton Decries U.N. 'Travesty', Calls For Syrian Coalition.” The Atlantic, 5 February 2012. https://www.theatlantic.com/international/archive/ 2012/o2/hillary-clinton-UN-veto-travesty-coalition-syria/332218/.

Bellamy, Alex J. Global Politics and The Responsibility to Protect: From Words to Deeds (London: Routledge, 2011).

Bellamy, Alex J., and Williams, Paul “The New Politics of Protection? Côte d' Ivoire, Libya and the Responsibility to Protect." International Affairs 87 (4) (2011), 825-850.

BP. Statistical Review of World Energy. June 2018. https:/www.bp.com/content/dam/ bp/business-sites/en/global/corporate/pdfs/energy-economics/statistical-review/ bp-stats-review-2018-full-report.pdf.

Brautigam, Deborah. The Dragon's Gift: The Real Story of China in Africa (Oxford: Oxford University Press, 2009).

Carlson, Allen. "Helping to Keep the Peace (Albeit Reluctantly): China's Recent Stance on Sovereignty and Multilateral Intervention." Pacific Affairs 77 (1) (2004), 9-27.

79 Johnston 2013, 39 . 
Carlson, Allen. Unifying China, Integrating with the World: Securing Chinese Sovereignty in the Reform Era (Stanford: Stanford University Press, 2005).

Carlson, Allen. "More than Just Saying No: China's Evolving Approach to Sovereignty and Intervention." In New Directions in the Study of Chinese Foreign Policy, eds. Alastair Iain Johnston and Robert Ross (Stanford: Stanford University Press, 2006), 217241.

"China Envoy Defends Africa Policy." BBC News, 4 June 2006. http://news.bbc.co.uk/1/ hi/world/asia-pacific/5045496.stm.

"China's Stake in the Syria Stand-Off." BBC News, 24 February 2012. http://www.bbc.co .uk/news/world-asia-china-17158889.

Crossley, Noele. "Is $\mathrm{R}_{2} \mathrm{P}$ Still Controversial? Continuity and Change in the Debate on 'Humanitarian Intervention." Cambridge Review of InternationalAffairs 31 (5) (2018), 415-436;

Davis, Jonathan E. “From Ideology to Pragmatism: China's Position on Humanitarian Intervention in the Post-Cold War Era." Vanderbilt Journal of Transnational Law 44 (2) (2011), 217-283.

Dittmer, Lowell. “Chinese Informal Politics.” China Journal 34 (1995), 1-34.

Finnemore, Martha. The Purpose of Intervention: Changing Beliefs about the Use of Force (Ithaca: Cornell University Press, 2004).

Foot, Rosemary, and Andrew Walter. China, the United States, and Global Order (New York: Cambridge University Press, 2011).

Fung, Courtney. "Separating Intervention from Regime Change? China's Diplomatic Innovations at the UN Security Council regarding the Syria Crisis." China Quarterly 235 (2018), 693-712.

Gao, Charlotte. "Why China Wants Syria in Its New Belt and Road." The Diplomat, 3o November 2017. https://thediplomat.com/2017/11/why-china-wants-syria-in-its-n ew-belt-and-road/.

Garwood-Gowers, Andrew. "China and the 'Responsibility to Protect': The Implications of the Libyan Intervention." Asian Journal of International Law 11 (1) (2013), 375393.

Gegout, Catherine. Why Europe Intervenes in Africa: Security, Prestige and the Legacy of Colonialism (New York: Oxford University Press, 2018).

Gong, Gerrit W. The Standard of "Civilization" in International Society (Oxford: Clarendon Press, 1984).

Grover, Sonja. The Responsibility to Protect: Perspectives on the Concept's Meaning, Proper Application and Value (Abingdon: Routledge, 2018).

Guo, Wanchao. Zhongguo jueqi: Yige dongfang daguo de chengzhang zhi dao (Nanchang: Guangxi renmin chubanshe, 2004).

He, Kai., and Feng, Huiyun. "Debating China's Assertiveness: Taking China's Power and Interests Seriously." International Politics 49 (5) (2012), 633-644. 
"Highlights of Xi's Speech at China-Arab Forum." China Daily, 10 July 2018. http://www .chinadaily.com.cn/a/201807/10/WS5b441634a3103349141e1cb7.html.

Hirono, Miwa., and Lanteigne, Marc. "Introduction: China and UN Peacekeeping." International Peacekeeping 18 (3) (2011), 243-256.

Jerdén, Bjoern. “The Assertive China Narrative: Why It Is Wrong and How so Many Still Bought into It." Chinese Journal of International Politics 7 (1) (2014), 47-88.

Johnston, Alastair I. "How New and Assertive Is China's New Assertiveness?" International Security 37 (4) (2013), 7-48.

Jones, Bruce. “'Intervention without Borders': Humanitarian Intervention in Rwanda, 1990-1994." Millennium 24 (2) (1995), 225-248.

Kent, Ann. China, the United Nations and Human Rights: The Limits of Compliance (Philadelphia: University of Pennsylvania Press, 1999).

Kim, Samuel S. China, the United Nations, and World Order (Princeton: Princeton University Press, 1979).

Layne, Christopher. "This time It's Real': The End of Unipolarity and the Pax Americana." International Studies Quarterly 56 (1) (2012), 203-213.

Liu, Tiewa, and Zhang, Haibin. "Debates in China about the Responsibility to Protect as a Developing International Norm: A General Assessment." Conflict, Security and Development 14 (4) (2014), 403-427.

Liu, Wenzong. "Lun guojifa zhong de zhuquan yu renquan-Mo 'renquan gaz yu zhuquan' miulun." Waijiao xueyuan xuebao 3 (1993), 38-43.

Luck, Edward. "Sovereignty, Choice and the Responsibility to Protect." Global Responsibility to Protect 1 (1) (2009), 10-21.

Luo, Yanhua. “'Baohu de zeren' de fazhan licheng yu zhongguo de lichang." Guoji zhengzhiyanjiu 3 (2014), 11-25.

Moravcova, Saerka. "The Controversy over Humanitarian Intervention and Responsibility to Protect." Perspectives 22 (2) (2014), 65-86.

Ogden, Suzanne. "The Approach of the Chinese Communists to the Study of International Law, State Sovereignty and the International System." China Quarterly 70 (1977), 315-337.

Paris, Roland. "The 'Responsibility to Protect' and the Structural Problems of Preventive Humanitarian Intervention." International Peacekeeping 21 (5) (2014), 569-6o3.

Permanent Mission of the People's Republic of China to the UN. "Explanation of Vote by Ambassador Li Baodong after Vote on Security Council Draft Resolution on Syria.” 4 February 2012. http://www.china-un.org/eng/hyyfy/tgo1712.htm.

"Preface." In Human Rights in China (White Paper). China.org.cn, November 1991. http:// www.china.org.cn/e-white/7/7-1.htm.

Price, Richard. The Chemical Weapons Taboo (Ithaca: Cornell University Press, 1997). $\mathrm{Qu}$, Xing. "The UN Charter, the Responsibility to Protect, and the Syria Issue." China International Studies 25 (101) (2012), 14-36. 
Risse, Thomas. "Let's Argue! Communicative Action in World Politics." International Organization 54 (1) (2000), 1-39.

Ross, Robert, and Feng Zhu, China's Ascent: Power, Security, and the Future of International Politics (Ithaca: Cornell University Press, 2015).

Roy, Denny. “Assertive China: Irredentism or Expansionism?" Survival 61 (1) (2019), 5174.

Ruan, Zongze. "Responsible Protection: Building a Safer World." 15 June 2012. China Institute of International Studies, http://www.ciis.org.cn/english/2012-06/15/conten t_5o9o912.htm.

Schoen, Douglas, and Melik Kaylan. The Russia-China Axis:The New Cold War and America's Crisis of Leadership (New York: Encounter Books, 2014).

Shambaugh, David. "China's Military Views the World." International Security 24 (3) (1999-2000), 52-79.

Suzuki, Shogo. Civilisation and Empire: China and Japan's Encounter with European International Society (London: Routledge, 2009).

Swaine, Michael. "Perceptions of an Assertive China." China Leadership Monitor 32 (2) (2010), 1-19.

“Syria Crisis: Hillary Clinton Calls UN Veto “Travesty.'”BBC News, 5 February 2012. http:// www.bbc.co.uk/news/world-middle-east-16896783.

Teitt, Sarah. "The Responsibility to Protect and China's Peacekeeping Policy." International Peacekeeping 18 (3) (2011), 298-312.

Tiezzi, Shannon. "Does China Approve of Russia's Airstrikes in Syria?" The Diplomat, 8 October 2015. http://thediplomat.com/2015/10/does-china-approve-of-russias-airs trikes-in-syria/.

UN. "Security Council Fails to Adopt Draft Resolution on Syria as Russian Federation, China Veto Text Supporting Arab League's Proposed Peace Plan." Press release, 4 February 2012.

UN. "Security Council Fails to Adopt Draft Resolution to End Attacks on Aleppo as Two Permanent Members Cast Veto." Press release SC/126o9, 5 December 2016a.

UN. "Security Council Fails to Adopt Resolution Condemning Chemical Weapons Use in Syria, Following Veto by Russian Federation." Press release, 12 April 2017 b.

UN. “UN Doc. S/PV.3988” 24 March 1999.

UN. "UN Doc. S/PV.6627” 4 October 2011.

UN, “UN Doc. S/PV.7038” 27 September 2013.

UN. “UN Doc. S/PV.7825” 5 December 2016b.

UN. "UN Doc. S/PV.7893" 28 February 2017 a.

UN. "Doc. S/PV.8228” 10 April 2018.

von Soest, Christian. "Democracy Prevention: The International Collaboration of Authoritarian Regimes." European Journal of Political Research 54 (4) (2015), 623-638. Wang, Hongying. 'From 'taoguang yanghui' to 'yousuo zuowei': China's Engagement in 
Financial Minilateralism." CIGI Papers No. $5^{2}$ (Waterloo, Ontario, Canada: Centre for International Governance Innovation, 2014).

Wang, Yizhou. "Zhuquan fanchu zai sikao." In Xin tiaozhan: Guojiguanxizhong de "rendao zhuyiganyu," ed. Yang Chengxu (Beijing: Zhongguo qingnian chubanshe, 2001), pp. 131-148.

Wong, Catherine. "China's UN Vote Abstention on Syria 'Part of Shift towards Balanced Diplomacy' in Middle East." The South China Morning Post, 13 April 2017. https:// www.scmp.com/news/china/diplomacy-defence/article/2087520/chinas-un-voteabstention-part-shift-towards-balanced.

Yan, Xuetong. "The Rise of China and Its Power Status." Chinese Journal of International Politics 1(1) (2006), 5-33.

Zhang, Yongjin. China in International Society since 1949: Alienation and beyond (Basingstoke: Macmillan, 1998).

Zhu, Feng. “'Rendao zhuyi ganshe': Gainian, wenti yu kunjing.” In Xin tiaozhan: Guoji guanxi zhong de "rendao zhuyi ganyu," ed. Yang Chengxu (Beijing: Zhongguo qingnian chubanshe, 2001), 179-197. 